Linköping Studies in Science and Technology

Dissertations, No. 1669

\title{
Evaluation, Generation, and Transformation of Driving Cycles
}

\author{
Peter Nyberg
}

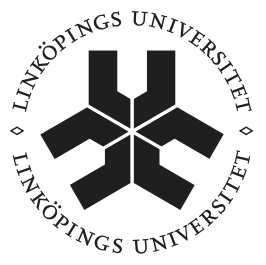

\section{Linköping University INSTITUTE OF TECHNOLOGY}

Department of Electrical Engineering

Linköping 2015 
Linköping Studies in Science and Technology

Dissertations, No. 1669

Peter Nyberg

peter.nyberg@liu.se

www.vehicular.isy.liu.se

Division of Vehicular Systems

Department of Electrical Engineering

Linköping University

SE-581 83 Linköping, Sweden

Copyright (C) 2015 Peter Nyberg, unless otherwise noted.

All rights reserved.

Nyberg, Peter

Evaluation, Generation, and Transformation of Driving Cycles

ISBN 978-91-7519-065-5

ISSN 0345-7524

Cover photo by Ryan McGuire. Available at pixabay.com and bound to the Creative Commons Deed CC0.

Typeset with $\operatorname{AT}_{\mathrm{E}} \mathrm{X} 2_{\varepsilon}$

Printed by LiU-Tryck, Linköping, Sweden 2015 
To Eva 



\section{ABSTRACT}

Driving cycles are important components for evaluation and design of vehicles. They determine the focus of vehicle manufacturers, and indirectly they affect the environmental impact of vehicles since the vehicle control system is usually tuned to one or several driving cycles. Thus, the driving cycle affects the design of the vehicle since cost, fuel consumption, and emissions all depend on the driving cycle used for design. Since the existing standard driving cycles cannot keep up with the changing road infrastructure, the changing vehicle fleet composition, and the growing number of vehicles on the road, which do all cause changes in the driver behavior, the need to get new and representative driving cycles are increasing. A research question is how to generate these new driving cycles so that they are both representative and at the same time have certain equivalence properties, to make fair comparisons of the performance results. Besides generation, another possibility to get more driving cycles is to transform the existing ones into new, different, driving cycles considering equivalence constraints.

With the development of new powertrain concepts the need for evaluation will increase, and an interesting question is how to utilize new developments in dynamometer technology together with new possibilities for connecting equipment. Here a pedal robot is developed to be used in a vehicle mounted in a chassis dynamometer and the setup is used for co-simulation together with a moving base simulator that is connected with a communication line. The results show that the co-simulation can become a realistic driving experience and a viable option for dangerous tests and a complement to tests on a dedicated track or on-road tests, if improvements on the braking and the vehicle feedback to the driver are implemented.

The problem of generating representative driving cycles, with specified excitation at the wheels, is approached with a combined two-step method. A Markov chain approach is used to generate candidate driving cycles that are then transformed to equivalent driving cycles with respect to the mean tractive force components, which are the used measures. Using an optimization methodology the transformation of driving cycles is formulated as a nonlinear program with constraints and a cost function to minimize. The nonlinear program formulation can handle a wide range of constraints, e.g., the mean tractive force components, different power measures, or available energy for recuperation, and using the vehicle jerk as cost function gives good drivability.

In conclusion, methods for driving cycle design have been proposed where new driving cycles can either be generated from databases, or given driving cycles can be transformed to fulfill certain equivalence constraints, approaching the important problem of similar but not the same. The combination of these approaches yields a stochastic and general method to generate driving cycles with equivalence properties that can be used at several instances during the product development process of vehicles. Thus, a powerful and effective engineering tool has been developed. 



\section{POPULÄRVETENSKAPLIG SAMMANFATTNING}

Enligt världshälsoorganisationen, WHO, dör miljontals människor i förtid till följd av luftföroreningar och en betydande del av dessa föroreningar kommer från utsläpp från transportsektorn. En förbättring av emissionsutsläppen och även bränsleförbrukningen för fordon ger således renare luft att andas och samtidigt kommer fordon att kunna köras längre mellan tankningarna.

Under en bilresa mellan hemmet och jobbet kommer bilen ha olika hastigheter vid olika tidpunkter. Denna hastighetsprofil kallas för en körcykel och för att säkerställa att biltillverkarna följer emissionslagstiftningen i Europa så behöver olika biltyper testas i en förutbestämd körcykel. Under ett sådant test mäts bland annat bränsleförbrukningen och den används av bilförsäljare, samt för beräkning av den årliga fordonsskatten. Hur körcykeln ser ut spelar stor roll för vilken bränsleförbrukning som fås i mätningen. Olika körcykler är olika krävande och ju mer krävande en körcykel är, desto högre blir bränsleförbrukningen. Detta innebär också att det i dagsläget är svårt att jämföra körcykler med varandra eftersom de påverkar fordonet på olika sätt.

Om en körcykel speglar hur människor normalt kör sina bilar på vägen kallas körcykeln för representativ. Körbeteendet påverkas av att nya vägar byggs, vi får snabbare fordon, nya koncept som hybrid- och elbilar utvecklas samt att det i stora delar av världen kommer allt fler fordon ut i trafiken. Detta innebär att även om en viss körcykel är representativ idag, så behöver den inte vara det i framtiden. Ett annat problem är då biltillverkarna använder sig av en specifik körcykel i en allt för stor utsträckning vid utveckling av styrsystemet. Detta kan leda till att fordonet blir mer anpassat till själva körcykeln än den verkliga användningen. Om körcykeln dessutom inte är representativ så finns det en överhängande risk att bilen får högre bränsleförbrukning vid verklig körning än vad testerna visar.

För att angripa dessa problem har det i denna avhandling tagits fram metoder dels för att generera nya körcykler och dels för att transformera de befintliga körcyklerna på ett sådant sätt att de nya körcyklerna både är representativa, samt har vissa egenskaper som gör att testresultat från de enklare kan jämföras med varandra. Kombinationen av dessa metoder ger fordonstillverkare nya möjligheter att skapa nya körcykler som kan användas vid utvecklingen av framtidens fordon.

I takt med att nya tekniska lösningar på fordonssidan presenteras ökar behovet av tester. Om till exempel en bil utrustas med ett specifikt förarstödsystem så är det viktigt att föraren känner förtroende för systemet. Ett nytt sätt att utvärdera sådana stödsystem på ett realistiskt sätt i en kontrollerad miljö som är säker för föraren och ger möjlighet till upprepade experiment, är att använda sig av en avancerad körsimulator hos VTI som är kopplad till en chassidynamometer med monterad bil i fordonslaboratoriet vid Linköpings universitet. Detta innebär att föraren upplever en riktig drivlina istället för en modell av den. En annan fördel av en sådan uppställning är att fordonet kommer att uppleva realistiska krafter eftersom körupplevelsen i körsimulatorn är nära verklig körning. Detta kan till exempel utnyttjas vid utvärdering av nya styrningsalgoritmer i fordonet. 



\section{ACKNOWLEDGMENTS}

This work has been carried out at the Division of Vehicular Systems at the Department of Electrical Engineering, Linköping University.

First of all, I would like to express my gratitude to my supervisors Lars Nielsen and Erik Frisk for the guidance and invaluable support during my Ph.D. studies.

I would like to thank Lars Eriksson for his inspiration in the field of research, it sparked an interest which finally led me to apply for a Ph.D. position. I am also grateful to Lars Nielsen for letting me join the Vehicular Systems group. A special thank of mine goes to my colleagues who have created a pleasant atmosphere at work, and you never know what kind of discussion topics that will pop up during the coffee breaks.

Per Öberg and Erik Frisk are acknowledged for all the computer-related support and the administrators Maria Hamnér and her predecessor Maria Hoffstedt both have been a helping hand during my time here. My thanks also goes to my roommate Kristoffer Lundahl for the company and all the discussions we have had. Åse Johansson and Eva Broman are acknowledged for proofreading parts of the thesis.

The financial support from the Swedish Hybrid Vehicle Centre, the Linnaeus Center CADICS, and the industrial partners are acknowledged. I would like to thank Tomas Nilsson, Christofer Sundström, Erik Frisk, and Mattias Krysander for our joint work related to the usage of wheel loaders. My thanks also go to Anders Andersson, Håkan Sehammar, and Per Öberg for their work in our joint paper.

I would like to express my warm thanks to my family and friends for all the good times we have had, and I hope we will continue to have many good times in the future. All of you mean a lot to me!

Last but definitely not least, I would like to express my greatest gratitude to the love of my life Eva for letting me know that there is more to life than just to work and write papers. Your support, encouragement, and love means everything to me and I will always be by your side.

Peter Nyberg

April 2015

Linköping, Sweden 



\section{Contents}

1 Introduction 1

1.1 Generation and Transformation of Driving Cycles . . . . . . . . . 4

1.2 Test Platforms for Evaluation of Vehicles . . . . . . . . . . . 6

1.3 Contributions . . . . . . . . . . . . . . . . . . 9

1.4 Publications . . . . . . . . . . . . . . . . . . 10

1.5 Outlook ....................... . . 11

1.6 Concluding Remark . . . . . . . . . . . . . . . . . . 12

References ....................... . . 13

$\begin{array}{ll}\text { Papers } & 19\end{array}$

A A New Chassis Dynamometer Laboratory for Vehicle Research 21

1 Introduction . . . . . . . . . . . . . . . . . 24

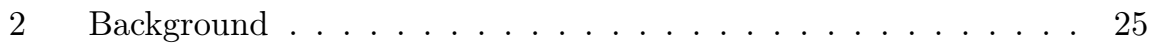

3 Laboratory Overview . . . . . . . . . . . . . . . . . 26

3.1 The Vehicle Propulsion Laboratory . . . . . . . . . . . . . 27

3.2 Equipment . . . . . . . . . . . . . . . . . . 28

4 Dynamometer System . . . . . . . . . . . . . . . . . 30

4.1 System Description . . . . . . . . . . . . . . . . . 30

4.2 Dynamometer Performance . . . . . . . . . . . . . 31

4.3 Mounting Procedure . . . . . . . . . . . . . . . 33

4.4 Test Modes . . . . . . . . . . . . . . . . . 33

5 Performed Studies . . . . . . . . . . . . . . . . 36

$5.1 \quad$ Modeling of Engine and Driveline Related Disturbances on the Wheel Speed in Passenger Cars . . . . . . . . . . . 37

5.2 Modeling and Control of Co-Surge in Bi-Turbo Engines . 37

5.3 Formula Student, Mapping . . . . . . . . . . . . . . 40

5.4 Chassis Dynamometer Road Force Co-Simulation with a Moving Base Simulator . . . . . . . . . . . . . . . . . 40

6 Future Projects Aims and Goals . . . . . . . . . . . . . . . . 42

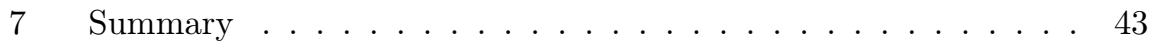

References ..................... . . 44 
B Vehicle Powertrain Test Bench Co-Simulation with a Moving Base Simulator Using a Pedal Robot

1 Introduction . . . . . . . . . . . . . . . . . . . . . 48

2 Experimental Setup . . . . . . . . . . . . . . . 48

$2.1 \quad$ Chassis Dynamometer Lab . . . . . . . . . . . . . . . 49

2.2 VTI Simulator III . . . . . . . . . . . . . . . . . . 53

2.3 Pedal Robot .................. . . . 54

2.4 Connection Between Facilities . . . . . . . . . . . . . . . . 57

2.5 Synchronizing Vehicle Models . . . . . . . . . . . . . 57

2.6 Driving Mission . . . . . . . . . . . . . . . 59

3 Results...................... 60

3.1 Network Performance . . . . . . . . . . . . . . 60

3.2 Step Response Tests of Pedal Robot . . . . . . . . . . . . 61

3.3 Running the Complete System . . . . . . . . . . . 62

4 Conclusions . . . . . . . . . . . . . . . . . . 67

References ........................ 68

C Using Real-World Driving Databases to Generate Driving Cycles with Equivalence Properties $\quad 69$

1 Introduction . . . . . . . . . . . . . . . . . . 72

1.1 Related Work . . . . . . . . . . . . . 72

1.2 Outline of Ideas and Paper . . . . . . . . . . . . . . . . . . . . . . . 74

2 Mean Tractive Force . . . . . . . . . . . . . . . . . . . . . . . . . 75

3 Equivalent Driving Cycles . . . . . . . . . . . . . . . . 77

$4 \quad$ Fuel Consumption Investigation . . . . . . . . . . . . . . . . . 78

4.1 Experimental Setup . . . . . . . . . . . . 78

4.2 Correlation of the MTF Components to Fuel Consumption 81

5 Driving Cycle Generation . . . . . . . . . . . . . . . . . 84

5.1 Real-World Driving Cycles . . . . . . . . . . . . 85

5.2 Markov Chains and the Transition Probability Matrix . . 86

5.3 Selection Criterion . . . . . . . . . . . . . . 89

5.4 Transformation to Equivalent Driving Cycles . . . . . . . 90

5.5 Method Summary . . . . . . . . . . . . . . 91

6 Results ........................... 91

6.1 Discussion ....................... 94

7 Conclusions . . . . . . . . . . . . . . . . . . . . 95

References......................... 97

D Driving Cycle Equivalence and Transformation 99

1 Introduction . . . . . . . . . . . . . . . . . . . . . . 102

1.1 Related Work . . . . . . . . . . . . . . 103

1.2 Outline ...................... 104

2 Characterization of Driving Cycles . . . . . . . . . . . 105

2.1 Vehicle Model . . . . . . . . . . . . . . . . . . . 105

2.2 Vehicle Operating Modes . . . . . . . . . . . . 106 
2.3 Mean Tractive Force Components . . . . . . . . . . . . 106

2.4 Power and Energy Demand . . . . . . . . . . . . . . 108

3 Driving Cycle Equivalence . . . . . . . . . . . . . . . . 108

4 Problem Formulation . . . . . . . . . . . . . . . . . . . . . 109

4.1 Transformable and Invariant Sets of the Driving Cycle . . 109

$4.2 \quad$ Fundamental Problem and Three Problem Instances . . . 110

5 Method: Numerical Optimization Approach . . . . . . . . . . . . 111

5.1 Constraints for Keeping the Traction and Non-Traction

Regions .................. . 112

5.2 Constraints from Maximum Acceleration . . . . . . . . . . 113

5.3 Constraints from Vehicle Excitation . . . . . . . . . . . 114

5.4 Power and Energy Recuperation Constraints . . . . . . . 115

5.5 Constraints on the Speed Profile . . . . . . . . . . . . 116

5.6 Cost Function . . . . . . . . . . . . . . . . . . 116

5.7 Method Summary and Discussion . . . . . . . . . . 116

6 Results ....................... 117

6.1 Incorporating a Speed Profile - P1 . . . . . . . . . . . 118

6.2 Transformation to Equivalent Driving Cycles - P2 . . . . 119

6.3 Changing the Power and Energy in a Driving Cycle - P3 . 122

7 Conclusions . . . . . . . . . . . . . . . . . 123

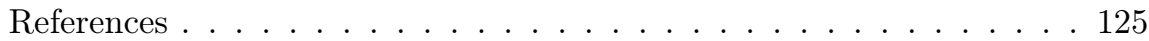





\section{Chapter 1}

\section{Introduction}

A driving cycle, or driving schedule, is represented by vehicle speed versus time. One important example is the European certification driving cycle for light-duty vehicles, the New European Driving Cycle, NEDC, shown in Figure 1.1. Other certification driving cycles that are used for test approval to control that the vehicle manufacturers follow the legislation are, e.g., the FTP75 used in the United States and the JC08 driving cycle which is used in Japan.

Driving cycles are important components for evaluating vehicles and play a fundamental role in vehicle design since the driving cycle affects the cost, fuel consumption, and the emissions of vehicles (Liaw and Dubarry, 2007; André and Rapone, 2009; Ericsson, 2000). In the past driving cycles have mainly been used to assess exhaust gas emissions of vehicles (André, 2004; André et al., 2006; Wang et al., 2000; Fontaras et al., 2009; Wang et al., 2008; Zervas and Bikas, 2008; Pelkmans and Debal, 2006) but they can also be used to evaluate different control strategies for vehicles as in (Pisu and Rizzoni, 2007; Koot et al., 2005; Manzie et al., 2007; Park et al., 2009; Gao et al., 2009; Stockar et al., 2011). Driving cycles have also been used in vehicle design and sizing of components (Maxoulis et al., 2004; Hellgren and Jonasson, 2007; Smith et al., 2011; Souffran et al., 2012; Murgovski et al., 2012; Jaafar et al., 2013; Pourabdollah et al., 2013; $\mathrm{Hu}$ et al., 2014).

The certification driving cycles are sometimes criticized to not be representative of real-world driving (Zaccardi and Le Berr, 2012; Souffran et al., 2012; Ashtari et al., 2014) which means that using them for evaluation and design could be questioned. A representative driving cycle usually means that several statistical measures, e.g., mean speed or proportion of time in cruising mode, of the driving cycle are close to real-world driving conditions. Even if a driving cycle is representative today there is no guarantee that it is still representative in the future since the development of the road network, changes in vehicle fleet composition, and the growing number of vehicles on the road causes changes 


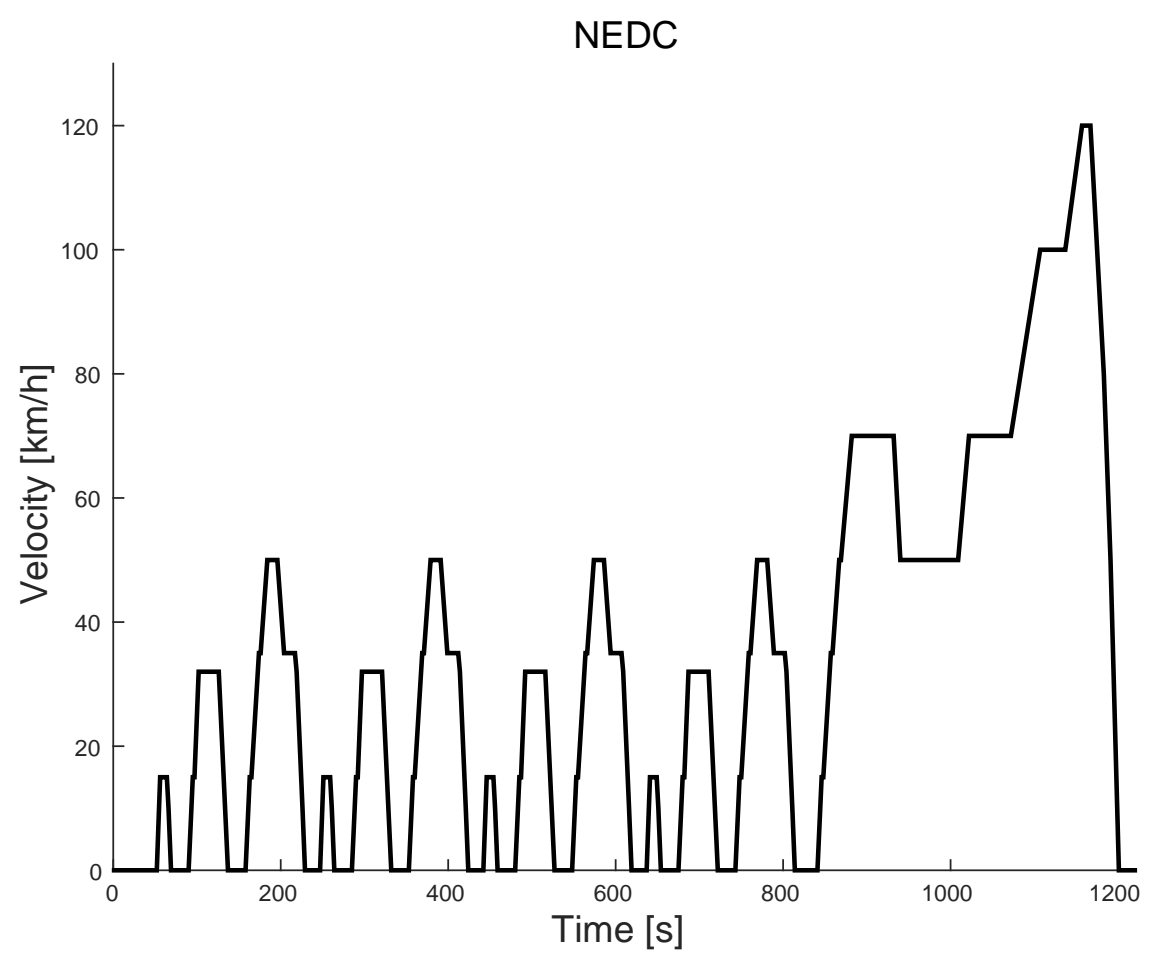

Figure 1.1: European certification driving cycle NEDC.

in the driving behavior, which also varies from region to region (André et al., 2006; Wang et al., 2008; Tong et al., 2011). Thus, there will always be a need for getting new representative driving cycles.

By using only a single driving cycle when designing a vehicle there is a considerable risk that the vehicle is optimized for this specific driving cycle and the resulting design may be non-robust and have sub-optimal performance for other driving cycles (Tazelaar et al., 2009; Schwarzer and Ghorbani, 2013). The vehicle manufacturers need then only to focus on limited operating regions of the engine (Pelkmans and Debal, 2006) and since other driving cycles may excite different regions of the engine, different exhaust gas emissions and fuel consumption characteristics are obtained. For example, Figure 1.2 shows the $\mathrm{NO}_{x}$ emissions for diesel cars for both the NEDC and the Common Artemis Driving Cycles, CADC, (André, 2004) driving cycles (T\&E Bulletin). The CADC reflects more of real-world driving compared to the NEDC and while the $\mathrm{NO}_{x}$ level in the NEDC is lower for each new generation of the legislation, the same is not true for the CADC. Further, the lower emission limit value in Euro 5 has not resulted in a reduction of $\mathrm{NO}_{x}$ emissions for diesel cars for real-world driving and it is not expected that these emissions will be close to 


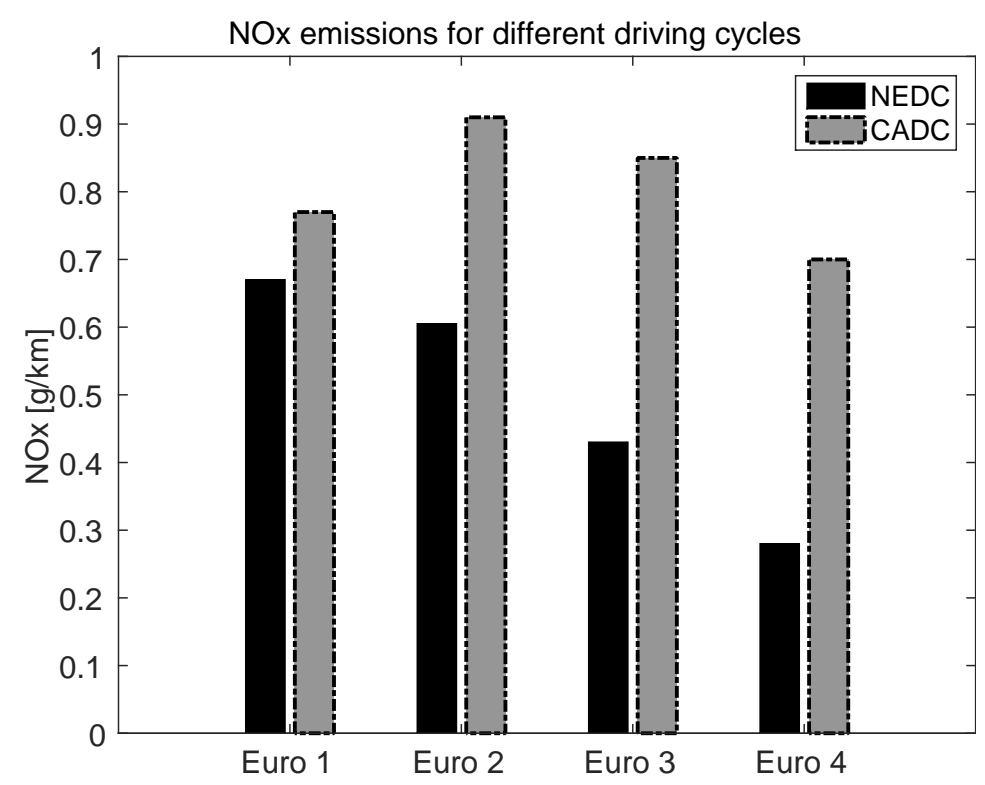

Figure 1.2: Comparison of $\mathrm{NO}_{x}$ emissions of diesel cars in the NEDC and CADC driving cycles for different European emission legislation.

the emission limit value of the NEDC in Euro 6 (Legerink et al., 2013). Thus, focusing on the NEDC is no guarantee that the controls are good in real-world driving conditions.

A common usage of driving cycles is to have different vehicles follow the same driving cycle, and then compare the results to, e.g., rank vehicles with respect to emission levels or fuel consumption. The fuel consumption figures from the certification driving cycles like the NEDC is one such comparison. Another use of driving cycles is to evaluate and compare certain control strategies (Koot et al., 2005; Pisu and Rizzoni, 2007; Tulpule et al., 2010). However, a direct comparison between driving cycles is not always a fair comparison (Zervas and Bikas, 2008). The reason for this is that different driving cycles excites the vehicle differently and the vehicle parameters determine the impact a certain driving cycle has on the vehicle. Figure 1.3 illustrates six different driving cycles with a corresponding fuel consumption shown. The low fuel consumption in the third driving cycle may be the result of a driving cycle which is less demanding to follow than, e.g., the fifth driving cycle which has the highest fuel consumption. Thus, one can not separate between the control and efficiency of the components and the vehicle parameters which can result in different power demand on the vehicle. However, if all driving cycles have similar vehicle excitation, a comparison of driving cycles would be more fair since then the effect of the vehicle parameters on the driving cycle demand would be similar. In such a case, the vehicle control 


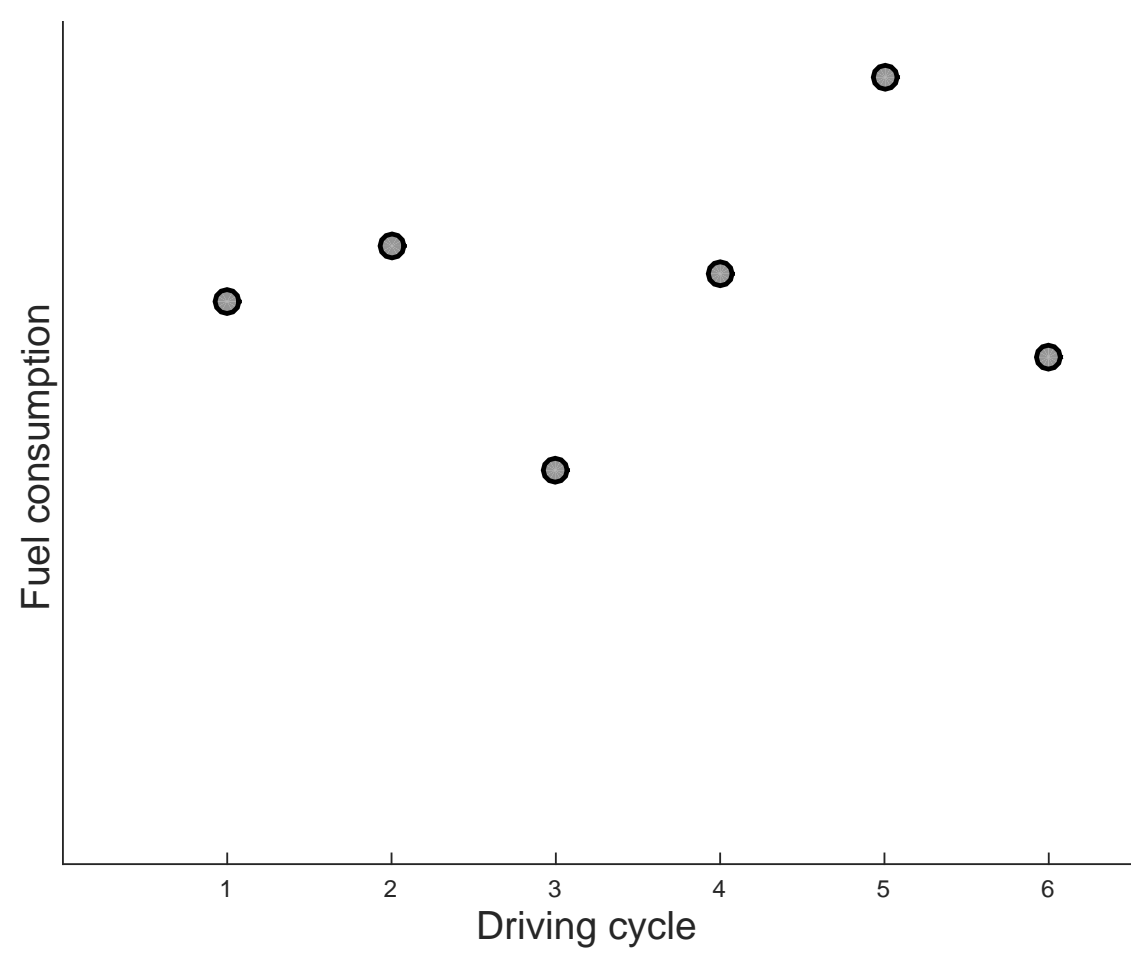

Figure 1.3: Illustration of fuel consumption for six different driving cycles.

and component efficiency can be evaluated to see which driving cycles that the control or the components are especially suited for, and in which driving cycles they perform poorly. This can be an indication on sub-optimal control and it can be further analyzed why a certain driving cycle is better, or worse, compared to other driving cycles. For example, assume that the third driving cycle is the NEDC and all driving cycles have similar vehicle excitation, one could suspect that the vehicle is well adapted to the NEDC and not well suited for the fifth driving cycle.

\subsection{Generation And Transformation of Driv- ING CYCLES}

From the previous section three problems were identified and these are regarding the representativeness of driving cycles, sub-optimization issues, and also how to perform a fair comparison of driving cycles. To solve the two former problems more representative driving cycles are needed to both increase the robustness and reduce the risk for sub-optimization. Today the vehicle manufacturers use several 
different driving cycles with the objective that they will cover and represent realworld driving, however, the abovementioned changing driving behavior results in a need to get more driving cycles. There are several approaches to generate new driving cycles that are representative for a certain region of interest, e.g., the Markov chain approaches in (Lee and Filipi, 2011; Gong et al., 2011; Souffran et al., 2012) that extract typical behavior from large amounts of operational data. There have been many proposals of new driving cycles that are representative of a certain region of interest, see, e.g., (Kent et al., 1978; Lin and Niemeier, 2002; Kamble et al., 2009; Shahidinejad et al., 2010; Tong et al., 2011). Another approach (Zaccardi and Le Berr, 2012) compared the existing standard driving cycles with objective methods, e.g., correlation analysis or automatic clustering, and chooses a combination of driving cycles that can be representative. However, comparison of driving cycles is still difficult to perform and the lack of a definition of representative driving cycles enables subjective judgments on how close these statistical measures need to be compared to real-world driving.

To make a fair comparison of the performance results obtained from different driving cycles it is important that the vehicle have similar excitation, e.g., regarding the forces acting on the vehicle in the different driving cycles. A driving cycle generation approach based on Markov chains combined with an equivalence transformation algorithm, is presented in Paper C. The Markov chain is parameterized using real-world driving cycles. The equivalence measures used are the mean tractive force components which are found to be correlated with the fuel consumption.

Another approach to get more driving cycles, besides generation of new driving cycles, is to transform existing ones into new, different, driving cycles. A motivational example is during a concept study where a new powertrain has substantial lower performance and the existing driving cycles cannot be used due to the required power exceeds the maximum power the new powertrain can deliver. Can the driving cycle be transformed in such a way that a performance comparison of the results between the driving cycles is fair and at the same time the vehicle is able to follow the new driving cycles? How to transform a given driving cycle into either a more demanding driving cycle or to a less demanding driving cycle is non-trivial if there are additional constraints that need to be considered. In (Carlson et al., 2009) the vehicle speed and time in the UDDS driving cycle (Kruse and Huls, 1973) was scaled by different factors resulting in an increase both in vehicle speed and acceleration while the traveled distance remained the same. Such an approach enables some control on certain measures but the level of control on other measures, e.g., the average power, are low. Paper D presents a general and systematic methodology for driving cycle transformation where a wide range of constraints can be handled and by using a cost function the vehicle jerk can be decreased simultaneously.

A flowchart on how to generate new driving cycles is shown in Figure 1.4. Here it is assumed that there exists a database of real-world driving cycles, which have been tagged with certain attributes regarding the measurement, e.g., vehicle 


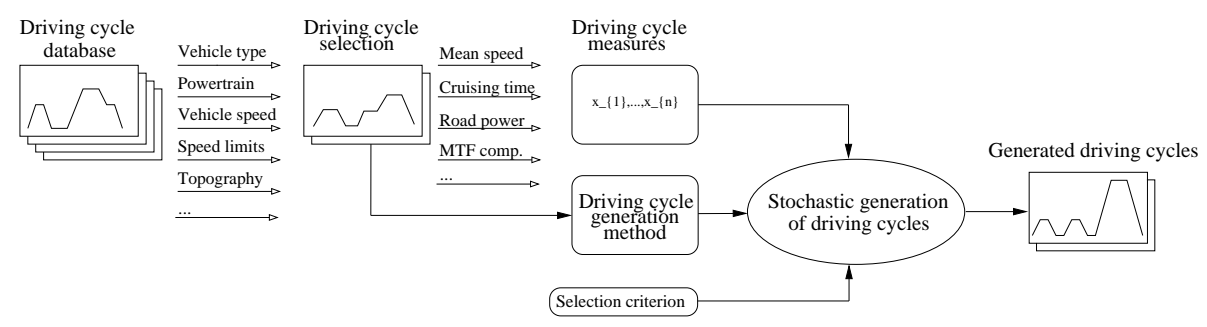

Figure 1.4: Schematic overview of a flowchart for driving cycle generation.

type, speed limits, or topography. From this database certain driving cycles are selected, e.g., all driving cycles driven in a certain region or only highway driving cycles with high mean speed. These driving cycles can be characterized by different measures, e.g., mean speed or road power. Using a certain driving cycle generation method together with a specified selection criterion, stochastic driving cycles with certain wanted properties can be generated. These driving cycle have different properties depending on which application they are used in. Figure 1.4 illustrates the approach used in Paper $\mathrm{C}$ where the driving cycle generation method uses Markov chains and as an additional step the generated driving cycles are transformed using an algorithm by Nyberg et al. (2013). The driving cycle transformation methodology in Paper D is more general and could be used instead.

These driving cycles that have either been measured, generated or transformed are used to evaluate and test vehicles. The vehicle evaluation can be performed in computer simulation software as in (Koot et al., 2005; Pisu and Rizzoni, 2007; Tulpule et al., 2010; Stockar et al., 2011) but for type approval the vehicle needs to follow the driving cycle in a chassis dynamometer. Another type of test platform is a moving base simulator and tests are also conducted on dedicated tracks and in real-traffic. In the next section a moving base simulator is combined with a chassis dynamometer to form a new hardware-in-the-loop test platform for vehicle evaluation.

\subsection{Test Platforms For Evaluation of Vehicles}

With increasing environmental concern, new powertrain technologies, e.g., hybrid electric vehicles and electric vehicles, with the objective to reduce the environmental footprint of vehicles, have been proposed and developed. How vehicles with these technologies are perceived by the drivers is important and it is furthermore vital to be able to conclude if a certain technology is better in practice and not just in a certain driving cycle. With the development of new experimental equipment, these kinds of questions can be addressed in a more systematic and repeatable way.

For evaluating the driver perception of the vehicle, a moving base simulator 
is a well-established technique and with improvements in power electronics and electrical drives new chassis dynamometer concepts have given opportunities to improve the existing usage and also enables possibilities to even connect such setups in a hardware-in-the-loop. Paper B presents a co-simulation of the chassis dynamometer in the vehicle propulsion laboratory (presented in Paper A) at Linköping University and the moving base simulator, Sim III, at the Swedish National Road and Transport Research Institute, VTI. These two setups are separated by a distance of 500 meter and are connected with a dedicated fiber link.

Sim III, the moving base driving simulator used in Paper B, is seen in Figure 1.5. It simulates the road conditions for vehicles (Bolling et al., 2011) and has in previous studies been used for, e.g., studying the effects of yaw stability at side impact in (Andersson and Jansson, 2011). The linear motion system of Sim III has four degrees of freedom and offers both linear and tilt motion. By linking the cradle motion to the vehicle's lateral position realistic lateral motions are obtained. Six projectors are used to give the driver a field of vision of 120 degrees. Road unevenness, which has high frequency, can be simulated by the vibration table and a Saab 9-3 cabin is currently used in Sim III.

Driving cycles are usually performed in chassis dynamometers (Kent et al., 1978) to, e.g., test the effect of different fuel types as in (Wang et al., 2000), or measuring tailpipe emissions for light-duty vehicles or trucks as in (Durbin et al., 2002; André, 2004; Pelkmans and Debal, 2006). Chassis dynamometer experiments are good alternatives to tests on a dedicated track or on-road tests since they give a higher repeatability, lower cost, and better experimental control and supervision. In the past chassis dynamometers usually meant rolls of different dimensions where the surfaces of the rolls are in direct contact with the tires of the vehicle, see, e.g., (Wang et al., 2000; Brace and Moffa, 2009; Carlson et al., 2009). However, in Paper A, a vehicle propulsion laboratory is presented that uses a different type of chassis dynamometer that is mounted directly to the wheel hubs, with the help of adapter plates. Thus, the wheel torques are extracted directly from the driven wheel hub connection instead from the friction between the tire and roll. The chassis dynamometer is shown in Figure 1.6 and consists of four mobile dynamometers which can operate both as motors and as generators depending on system mode, and can thus both brake and propel the vehicle. The outputs of the dynamometer are wheel torques and rotational wheel speeds but also vehicle speed and other quantities that can be calculated using the internal vehicle model.

Paper B develops and evaluates a co-simulation of a chassis dynamometer and a moving base simulator. The purpose of such a setup is to try to improve the driving experience in Sim III and at the same time the vehicle mounted in the chassis dynamometer is experiencing more realistic loads due to that the driver's perception of the simulation is closer to reality. Previous work used an internet-distributed hardware-in-the-loop simulation of an engine test bench and 


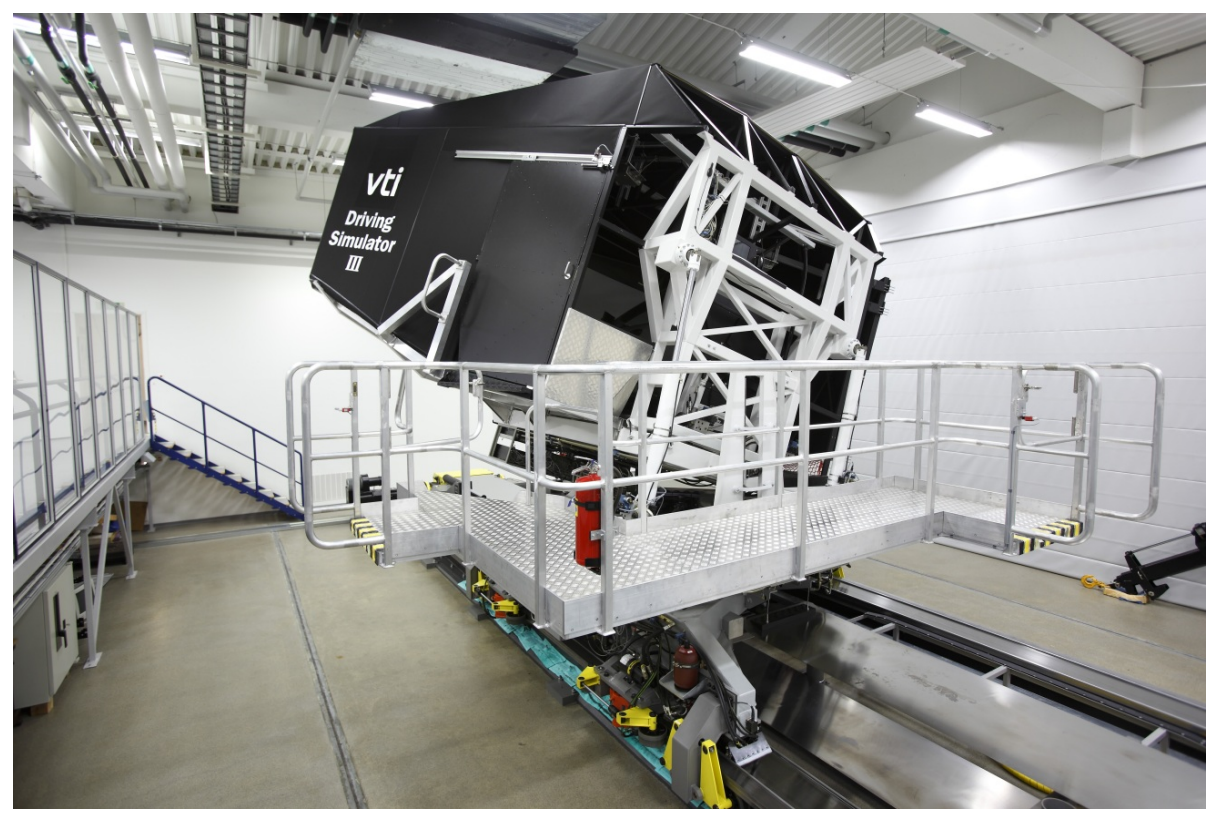

Figure 1.5: Moving base simulator Sim III.

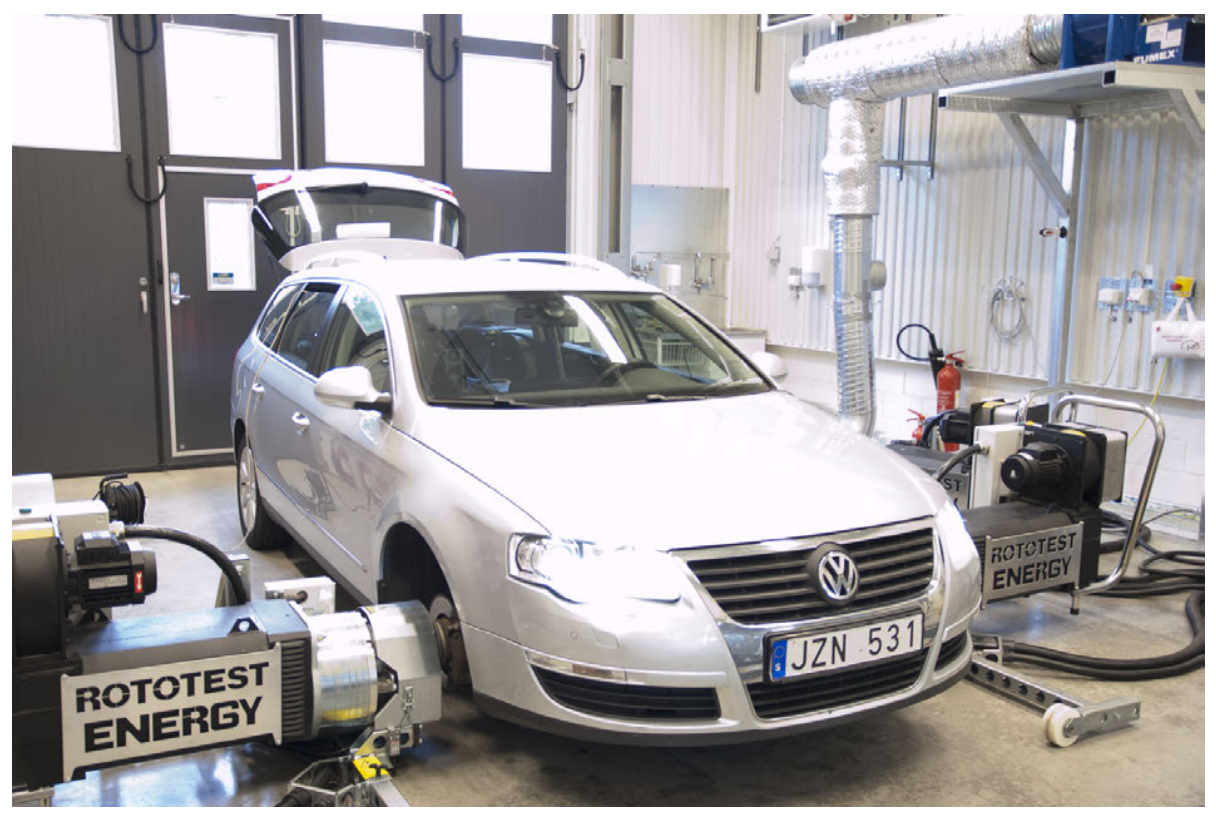

Figure 1.6: Volkswagen Passat mounted in the chassis dynamometer in the vehicle propulsion laboratory. 
a ride motion simulator (Ersal et al., 2011). The co-simulation is made possible with the development of a pedal robot that actuates the driver's input in the moving base simulator to the mounted vehicle. In the experiment a front-wheel-driven Volkswagen Passat Ecofuel DSG from 2009 was used. The vehicle, shown in Figure 1.6, has an automatic transmission meaning no gearshifting robot was required.

The vehicle model in Sim III was modified to accept inputs from the vehicle propulsion laboratory. This means that the chassis dynamometer at the propulsion laboratory controls the propulsion of the vehicle during the co-simulation but the other parts of the simulator are intact providing a realistic environment to the driver in the Sim III. During a driving mission the driver, in Sim III, actuates the accelerator and brake pedal both in Sim III and also in the mounted vehicle in the chassis dynamometer via the pedal robot. The resulting wheel torques, from the powertrain, are measured and both torques and wheel speeds are sent to the Sim III and forms a loop. Using this new laboratory setup, new powertrain technologies can be tested in a controlled and realistic setting and can be a complement to on-road tests.

The resulting vehicle speed trace of such an experiment could be compared to, e.g., on-road tests, to determine if there are any differences in driver behavior in the co-simulation compared to real-world driving. Such an evaluation of the setup has the benefit of being objective compared to subjective answers from test persons in the study.

\subsection{Contributions}

The main contributions of Papers A - D are summarized below.

\section{PAPER A}

Paper A presents the vehicle propulsion laboratory for vehicle research where a chassis dynamometer is used to test light-duty vehicles. The contribution is the development of a new chassis dynamometer laboratory and its design choices. The laboratory hardware such as data acquisition, network infrastructure, and the chassis dynamometer, its performance, and possible usage are discussed. The vehicle propulsion laboratory is a requirement for the co-simulation study in Paper B. The author of this thesis contributed with equal amount of work compared to the first author of Paper A and it includes design, conducting the experiments, implementation, and the written presentation.

\section{PAPER B}

Paper B presents a new engineering tool for vehicle testing in a controlled environment by connecting the chassis dynamometer in the vehicle propulsion 
laboratory to the moving base simulator Sim III. The contribution is a proofof-concept that the configuration works and with some improvements can be a realistic environment for vehicle testing. The author of this thesis contributed with equal amount of work compared to his co-authors of Paper B and it includes design, conducting the experiments, implementation, and the written presentation.

\section{PAPER C}

Paper $\mathrm{C}$ presents an approach to generate driving cycles with certain desired equivalence properties from a database of real-world driving cycles. The contribution is the experimental investigation that shows a gain in using the individual components of the mean tractive force, MTF, compared of the aggregated MTF, as an indication of the fuel consumption in the driving cycle. The experiments were conducted in a hardware-in-the-loop setup with a real engine. A second contribution is the combination of using a Markov chain approach to generate candidate driving cycle and then use a transformation algorithm in (Nyberg et al., 2013) to get driving cycles with the same vehicle excitation regarding the mean tractive force components. The author of this thesis contributed with the majority of this work including design and the implementation. Paper $\mathrm{C}$ relies partly on work presented in (Nyberg et al., 2013, 2014).

\section{PAPER D}

Paper D presents a methodology for transforming driving cycles. The contribution is a methodology that can be used to transform a given driving cycle into a new, different, driving cycle considering general constraints. An evaluation of the method shows that all tested problems are solved swiftly and it can handle a wide range of constraints on the driving cycle. The method is straightforward to use and gives an effective new engineering tool for driving cycle design. The author of this thesis contributed with the majority of this work including design and the implementation. Paper D relies partly on the ideas in (Nyberg et al., 2013).

\subsection{Publications}

The research work leading to this thesis is presented in the following publications.

\section{JOURNAL PAPERS}

- P. Öberg, P. Nyberg, and L. Nielsen. A new chassis dynamometer laboratory for vehicle research. SAE International Journal of Passenger Cars Electronic and Electrical Systems, 6(1):152-161, 2013 (Paper A) 
- A. Andersson, P. Nyberg, H. Sehammar, and P. Öberg. Vehicle powertrain test bench co-simulation with a moving base simulator using a pedal robot. SAE International Journal of Passenger Cars - Electronic and Electrical Systems, 6(1):169-179, 2013 (Paper B)

- T. Nilsson, P. Nyberg, C. Sundström, E. Frisk, and M. Krysander. Robust driving pattern detection and identification with a wheel loader application. International Journal of Vehicle Systems Modelling and Testing, 9(1):56-76, 2014

\section{SubmitTED}

- P. Nyberg, E. Frisk, and L. Nielsen. Using real-world driving databases to generate driving cycles with equivalence properties. 2015a. Submitted for journal publication (Paper C)

- P. Nyberg, E. Frisk, and L. Nielsen. Driving cycle equivalence and transformation. 2015b. Submitted for journal publication (Paper D)

\section{Conference Papers}

- P. Nyberg, E. Frisk, and L. Nielsen. Driving cycle adaption and design based on mean tractive force. In Proceedings of 7th IFAC Symposium on Advances in Automotive Control, volume 7, pages 689-694, Tokyo, Japan, 2013

- P. Nyberg, E. Frisk, and L. Nielsen. Generation of equivalent driving cycles using markov chains and mean tractive force components. In Proceedings of 19th IFAC World Congress, volume 19, pages 8787-8792, Cape Town, South Africa, 2014

\subsection{OutLOOK}

The methodology presented in Paper D enables transformation of driving cycles in a controlled and systematic way, and yields possibilities to increase both the robustness and the sensitivity of the control of vehicles. For example, the sensitivity of the sizing of the energy buffer or the fuel consumption in a hybrid electric vehicle, of the recuperation energy can be evaluated by changing the available recuperation energy in the driving cycle. Combining a driving cycle generation tool, e.g., the Markov chain approach used in Paper C, with the general driving cycle transformation methodology presented in Paper D yields a powerful tool that can be used at several instances during the product development process of vehicles.

An interesting continuation would be to include the road slope as an extra state. In the Markov chain approach of generation of driving cycles this corresponds to use three states; vehicle speed, acceleration, and road slope as in 
(Souffran et al., 2012). The transformation methodology in Paper D would have to be extended to also consider the road slope and not just the vehicle speed points as optimization variables.

The performance of the fiber link between the two laboratories in Paper $\mathrm{A}$ and $\mathrm{B}$ was not an issue. However, an interesting continuation would be to conduct studies for examining the effect of delays and lost packages on the driving experience. For example, what is an acceptable delay, both for the driver and the system, in such a setup can be a research question.

\subsection{CONCLUding REMARK}

Previously, changing how demanding a driving cycle is to follow for a vehicle usually consisted of either changing the vehicle speed and time by scaling as in (Carlson et al., 2009), or by just extending the driving cycle by consecutive repetitions of itself as in (Tulpule et al., 2010). The former case enables some control on the vehicle speed and acceleration but other measures such as average power can not be directly included. Consecutive repetitions of the same driving cycle increases the length and thus the required total energy but keeps the speed and acceleration characteristics.

Now, using the methodology presented in Paper D the transformation of a driving cycle is controlled and target measures such as mean tractive force components, average power, and available energy for recuperation can be formulated as constraints. Thus, a general and systematic methodology for changing the driving cycle demand on the vehicle has been developed. 


\section{REFERENCES}

A. Andersson and J. Jansson. A moving base simulator investigation of effects of a yaw stability system caused by a side impact. ASME/Journal of Computing and Information Science in Engineering, 11(4), 2011.

A. Andersson, P. Nyberg, H. Sehammar, and P. Öberg. Vehicle powertrain test bench co-simulation with a moving base simulator using a pedal robot. $S A E$ International Journal of Passenger Cars - Electronic and Electrical Systems, 6 (1):169-179, 2013.

M. André and M. Rapone. Analysis and modelling of the pollutant emissions from European cars regarding the driving characteristics and test cycles. Atmospheric Environment, 43(5):986-995, 2009.

M. André. The ARTEMIS European driving cycles for measuring car pollutant emissions. Science of The Total Environment, 334-335(0):73-84, 2004.

M. André, R. Joumard, R. Vidon, P. Tassel, and P. Perret. Real-world European driving cycles, for measuring pollutant emissions from high- and low-powered cars. Atmospheric Environment, 40(31):5944-5953, 2006. 13th International Symposium on Transport and Air Pollution (TAP-2004).

A. Ashtari, E. Bibeau, and S. Shahidinejad. Using large driving record samples and a stochastic approach for real-world driving cycle construction: Winnipeg driving cycle. Transportation Science, 48(2):170-183, 2014.

A. Bolling, J. Jansson, M. Hjort, M. Lidström, S. Nordmark, H. Sehammar, and L. Sjögren. An approach for realistic simulation of real road condition in a moving base driving simulator. ASME/Journal of Computing and Information Science in Engineering, 11(4), 2011.

C. J. Brace and J. Moffa. Increasing accuracy and repeatability of fuel consumption measurement in chassis dynamometer testing. Journal of Automobile Engineering, 223(9):1163-1177, 2009.

R. Carlson, H. Lohse-Busch, M. Douba, and N. Shidore. Drive cycle fuel consumption variability of plug-in hybrid electric vehicles due to aggressive driving. In SAE Technical paper 2009-01-1335, Detroit, USA, 2009.

T. D. Durbin, R. D. Wilson, J. M. Norbeck, J. Miller, T. Huai, and S. H. Rhee. Estimates of the emission rates of ammonia from light-duty vehicles using standard chassis dynamometer test cycles. Atmospheric Environment, 36 (9):1475-1482, 2002.

E. Ericsson. Variability in urban driving patterns. Transportation Research Part D: Transport and Environment, 5(5):337-354, 2000. 
T. Ersal, M. Brudnak, A. Salvi, J. Stein, Z. Filipi, and H. Fathy. Development and model-based transparency analysis of an internet-distributed hardware-inthe-loop simulation platform. Mechatroncis, 21:22-29, 2011.

G. Fontaras, G. Karavalakis, M. Kousoulidou, T. Tzamkiozis, L. Ntziachristos, E. Bakeas, S. Stournas, and Z. Samaras. Effects of biodiesel on passenger car fuel consumption, regulated and non-regulated pollutant emissions over legislated and real-world driving cycles. Fuel, 88(9):1608-1617, 2009.

J.-P. Gao, G.-M. G. Zhu, E. G. Strangas, and F.-C. Sun. Equivalent fuel consumption optimal control of a series hybrid electric vehicle. Proceedings of the Institution of Mechanical Engineers, Part D: Journal of Automobile Engineering, 223(8):1003-1018, 2009.

Q. Gong, S. Midlam-Mohler, V. Marano, and G. Rizzoni. An iterative markov chain approach for generating vehicle driving cycles. SAE International Journal of Engines, 4(1):1035-1045, 2011.

J. Hellgren and E. Jonasson. Maximisation of brake energy regeneration in a hybrid electric parallel car. International Journal of Electric and Hybrid Vehicles, 1(1):95-121, 2007.

X. Hu, N. Murgovski, L. Johannesson, and B. Egardt. Comparison of three electrochemical energy buffers applied to a hybrid bus powertrain with simultaneous optimal sizing and energy management. IEEE Transactions on Intelligent Transportation Systems, 15(3):1193-1205, 2014.

A. Jaafar, B. Sareni, and X. Roboam. A systemic approach integrating driving cycles for the design of hybrid locomotives. IEEE Transactions on Vehicular Technology, 62(8):3541-3550, 2013.

S. Kamble, T. Mathew, and G. Sharma. Development of real-world driving cycle: Case study of Pune, India. Trans. Research Part D, 14(2):132-140, 2009.

J. Kent, G. Allen, and G. Rule. A driving cycle for Sydney. Transportation Research, 12(3):147-152, 1978.

M. Koot, J. Kessels, B. de Jager, W. Heemels, P. van den Bosch, and M. Steinbuch. Energy management strategies for vehicular electric power systems. IEEE Transactions on Vehicular Technology, 54(3):771-782, May 2005.

R. E. Kruse and T. A. Huls. Development of the federal urban driving schedule. In SAE Technical Paper 730553, 1973.

T.-K. Lee and Z. Filipi. Synthesis of real-world driving cycles using stochastic process and statistical methodology. International Journal of Vehicle Design, 57(1):17-36, 2011. 
N. Legerink, G. Kadijk, P. van Mensch, S. Hausberger, and M. Rexeis. Investigations and real world emission performance of Euro 6 light-duty vehicles. Technical report, TNO, 2013.

B. Liaw and M. Dubarry. From driving cycle analysis to understanding battery performance in real-life electric hybrid vehicle operation. Journal of Power Sources, 174(1):76-88, 2007.

J. Lin and D. Niemeier. An exploratory analysis comparing a stochastic driving cycle to California's regulatory cycle. Atmospheric Environment, 36 (38):5759-5770, 2002.

C. Manzie, H. Watson, and S. Halgamuge. Fuel economy improvements for urban driving: Hybrid vs. intelligent vehicles. Transportation Research Part C: Emerging Technologies, 15(1):1-16, 2007.

C. N. Maxoulis, D. N. Tsinoglou, and G. C. Koltsakis. Modeling of automotive fuel cell operation in driving cycles. Energy Conversion and Management, 45 (4):559-573, 2004.

N. Murgovski, L. Johannesson, J. Sjöberg, and B. Egardt. Component sizing of a plug-in hybrid electric powertrain via convex optimization. Mechatronics, 22(1):106-120, 2012.

T. Nilsson, P. Nyberg, C. Sundström, E. Frisk, and M. Krysander. Robust driving pattern detection and identification with a wheel loader application. International Journal of Vehicle Systems Modelling and Testing, 9(1):56-76, 2014.

P. Nyberg, E. Frisk, and L. Nielsen. Driving cycle adaption and design based on mean tractive force. In Proceedings of 7th IFAC Symposium on Advances in Automotive Control, volume 7, pages 689-694, Tokyo, Japan, 2013.

P. Nyberg, E. Frisk, and L. Nielsen. Generation of equivalent driving cycles using markov chains and mean tractive force components. In Proceedings of 19th IFAC World Congress, volume 19, pages 8787-8792, Cape Town, South Africa, 2014.

P. Nyberg, E. Frisk, and L. Nielsen. Using real-world driving databases to generate driving cycles with equivalence properties. 2015a. Submitted for journal publication.

P. Nyberg, E. Frisk, and L. Nielsen. Driving cycle equivalence and transformation. 2015b. Submitted for journal publication.

P. Öberg, P. Nyberg, and L. Nielsen. A new chassis dynamometer laboratory for vehicle research. SAE International Journal of Passenger Cars - Electronic and Electrical Systems, 6(1):152-161, 2013. 
J. Park, Z. Chen, L. Kiliaris, M. Kuang, M. Masrur, A. Phillips, and Y. Murphey. Intelligent vehicle power control based on machine learning of optimal control parameters and prediction of road type and traffic congestion. IEEE Transactions on Vehicular Technology, 58(9):4741-4756, 2009.

L. Pelkmans and P. Debal. Comparison of on-road emissions with emissions measured on chassis dynamometer test cycles. Transportation Research Part D: Transport and Environment, 11(4):233-241, 2006.

P. Pisu and G. Rizzoni. A comparative study of supervisory control strategies for hybrid electric vehicles. IEEE Transactions on Control Systems Technology, 15(3):506-518, May 2007.

M. Pourabdollah, N. Murgovski, A. Grauers, and B. Egardt. Optimal sizing of a parallel PHEV powertrain. IEEE Transactions on Vehicular Technology, 62 (6):2469-2480, 2013.

V. Schwarzer and R. Ghorbani. Drive cycle generation for design optimization of electric vehicles. IEEE Transactions on Vehicular Technology, 62(1):89-97, 2013.

S. Shahidinejad, E. Bibeau, and S. Filizadeh. Statistical development of a duty cycle for plug-in vehicles in a North American urban setting using fleet information. IEEE Transactions on Vehicular Technology, 59(8):3710-3719, 2010 .

R. Smith, S. Shahidinejad, D. Blair, and E. Bibeau. Characterization of urban commuter driving profiles to optimize battery size in light-duty plug-in electric vehicles. Transportation Research Part D: Transport and Environment, 16(3): 218-224, 2011.

G. Souffran, L. Miegeville, and P. Guerin. Simulation of real-world vehicle missions using a stochastic markov model for optimal powertrain sizing. IEEE Transactions on Vehicular Technology, 61(8):3454-3465, 2012.

S. Stockar, V. Marano, M. Canova, G. Rizzoni, and L. Guzzella. Energy-optimal control of plug-in hybrid electric vehicles for real-world driving cycles. IEEE Transactions on Vehicular Technology, 60(7):2949-2962, 2011.

E. Tazelaar, J. Bruinsma, B. Veenhuizen, and P. van den Bosch. Driving cycle characterization and generation, for design and control of fuel cell buses. World Electric Vehicle Journal, 3(1), 2009.

T\&E Bulletin. Who adds pressure for stricter Euro-5 standards. Number 146, March 2006.

H. Tong, H. Tung, W. Hung, and H. Nguyen. Development of driving cycles for motorcycles and light-duty vehicles in Vietnam. Atmospheric Environment, 45(29):5191-5199, 2011. 
P. Tulpule, V. Marano, and G. Rizzoni. Energy management for plug-in hybrid electric vehicles using equivalent consumption minimisation strategy. International Journal of Electric and Hybrid Vehicles, 2(4):329-350, 2010.

Q. Wang, H. Huo, K. He, Z. Yao, and Q. Zhang. Characterization of vehicle driving patterns and development of driving cycles in Chinese cities. Transportation Research Part D: Transport and Environment, 13(5):289-297, 2008.

W. Wang, D. Lyons, N. Clark, M. Gautam, and P. Norton. Emissions from nine heavy trucks fueled by diesel and biodiesel blend without engine modification. Environmental Science and Technology, 34(6):933-939, 2000.

J.-M. Zaccardi and F. Le Berr. Analysis and choice of representative drive cycles for light duty vehicles - Case study for electric vehicles. Proceedings of the Institution of Mechanical Engineers, Part D: Journal of Automobile Engineering, 2012.

E. Zervas and G. Bikas. Impact of the driving cycle on the $\mathrm{NO}_{\mathrm{x}}$ and particulate matter exhaust emissions of diesel passenger cars. Energy and Fuels, 22(3): 1707-1713, 2008. 

Papers 



\section{Papers}

The articles associated with this thesis have been removed for copyright reasons. For more details about these see:

http://urn.kb.se/resolve?urn=urn:nbn:se:liu:diva-117549 
Linköping Studies in Science and Technology, Dissertations

Division of Vehicular Systems

Department of Electrical Engineering

Linköping University

No 1 Magnus Pettersson, Driveline Modeling and Control, 1997.

No 2 Lars Eriksson, Spark Advance Modeling and Control, 1999.

No 3 Mattias Nyberg, Model Based Fault Diagnosis: Methods, Theory, and Automotive Engine Applications, 1999.

No 4 Erik Frisk, Residual Generation for Fault Diagnosis, 2001.

No 5 Per Andersson, Air Charge Estimation in Turbocharged Spark Ignition Engines, 2005.

No 6 Mattias Krysander, Design and Analysis of Diagnosis Systems Using Structural Methods, 2006.

No 7 Jonas Biteus, Fault Isolation in Distributed Embedded Systems, 2007.

No 8 Ylva Nilsson, Modelling for Fuel Optimal Control of a Variable Compression Engine, 2007.

No 9 Markus Klein, Single-Zone Cylinder Pressure Modeling and Estimation for Heat Release Analysis of SI Engines, 2007.

No 10 Anders Fröberg, Efficient Simulation and Optimal Control for Vehicle Propulsion, 2008.

No 11 Per Öberg, A DAE Formulation for Multi-Zone Thermodynamic Models and its Application to CVCP Engines, 2009.

No 12 Johan Wahlström, Control of EGR and VGT for Emission Control and Pumping Work Minimization in Diesel Engines, 2009.

No 13 Anna Pernestål, Probabilistic Fault Diagnosis with Automotive Applications, 2009.

No 14 Erik Hellström, Look-ahead Control of Heavy Vehicles, 2010.

No 15 Erik Höckerdal, Model Error Compensation in ODE and DAE Estimators with Automotive Engine Applications, 2011. 
No 16 Carl Svärd, Methods for Automated Design of Fault Detection and Isolation Systems with Automotive Applications, 2012.

No 17 Oskar Leufvén, Modeling for Control of Centrifugal Compressors, 2013.

No 18 Christofer Sundström, Model Based Vehicle Level Diagnosis for Hybrid Electric Vehicles, 2014.

No 19 Andreas Thomasson, Modeling and Control of Actuators and Co-Surge in Turbocharged Engines, 2014.

No 20 Emil Larsson, Model Based Diagnosis and Supervision of Industrial Gas Turbines, 2014.

No 21 Andreas Myklebust, Dry Clutch Modeling, Estimation, and Control, 2014.

No 22 Tomas Nilsson, Optimal Predictive Control of Wheel Loader Transmissions, 2015. 